\title{
Refractive outcomes of laser- treated and non-laser-treated retinopathy of prematurity at Hospital Selayang: a 2-year retrospective review
}

Aasiah Ahmad Sharifuddin ${ }^{1,3}$, Fiona Lee Min Chew $^{2}$, Irina Effendi-Tenang ${ }^{3}$, Amir Samsudin ${ }^{3}$

${ }^{1}$ Department of Ophthalmology, Hospital Selayang, Selangor, Malaysia; ${ }^{2}$ Department of Ophthalmology, Sunway Medical Centre, Velocity, Kuala Lumpur; ${ }^{3}$ Department of Ophthalmology, University of Malaya Medical Centre, Kuala Lumpur, Malaysia

\section{Abstract}

Objective: To compare the refractive outcomes of laser-treated and non-laser-treated retinopathy of prematurity (ROP) infant, at 2 years of age in Hospital Selayang. Methods: Retrospective review involving patients born between 2016 and 2018. They were divided into those who were treated with laser photocoagulation, and those who were observed. Laser treatment was given to infants with threshold and high-risk, pre-threshold disease. Refractive error was identified by cycloplegic refraction at 2 years of age.

Results: There were 22 eyes from 11 infants in the laser-treated group, all of which had zone II ROP with plus disease; of these, four had stage 2 ROP and 18 had stage 3 ROP. There were 53 eyes from 28 patients in the non-laser-treated group. The mean birth weight for the laser-treated and non-laser-treated groups was $966.9 \pm 92.6 \mathrm{~g}$ and $1019.3 \pm 282.0 \mathrm{~g}$, respectively $(P=0.398)$. Mean gestational age for the laser-treated and non-laser-treated groups was $28.2 \pm 2.2$ weeks and $27.7 \pm 2.2$ weeks, respectively $(P=0.390)$. At 2 years, the mean spherical equivalence for the laser-treated and non-laser treated groups was $-0.55 \pm 2.49 \mathrm{D}$ and $+0.17 \pm 1.43 \mathrm{D}$, respectively, although the difference was not statistically significant $(P=0.120)$. Myopia was

Correspondence: Aasiah Ahmad Sharifuddin, MBBS, Department of Ophthalmology, Faculty of Medicine, University of Malaya, 50603 Kuala Lumpur.

E-mail: aasiahahmad2@yahoo.com 
commoner in the laser-treated group (six eyes [27\%] vs five eyes [9\%], $P=0.047$ ), and two eyes from two different infants (10\%) from this group also developed high myopia $(>-6.00 \mathrm{D})$. For hypermetropia and astigmatism, there were no statistically significant differences between the groups (all $P>0.05$ ). High myopia was strongly related to the post-conceptual age when receiving laser therapy $(P=0.025)$. In the laser-treated group, two infants (9\%) had amblyopia and one (5\%) had exotropia at 2 years of age. None of the eyes developed structural retinal sequelae.

Conclusion: Despite successful treatment of ROP, a significant number of laser-treated eyes developed myopia. This highlights the need for long-term refractive screening in these patients.

Keywords: laser, Malaysia, myopia, refractive error, retinopathy of prematurity

\section{Hasil refraksi bayi retinopati pra-matang yang dirawat dan tidak dirawat dengan laser di Hospital Selayang: Kajian retrospektif 2 tahun}

\section{Abstrak}

Objektif: Membandingkan hasil refraksi bayi pra-matang yang mempunyai masalah retinopati pra-matang (ROP) yang dirawat dengan laser dengan yang tidak diberikan rawatan laser di Hospital Selayang.

Metodologi: Reviu retrospektif melibatkan bayi yang dilahirkan diantara 2016 dan 2018. Bayi pra-matang dengan ROP dibahagikan kepada 2 kumpulan iaitu yang dirawat dan yang tidak dirawat menggunakan laser. Rawatan laser diberikan untuk kes ambang dan pra-ambang yang berisiko tinggi. Nilai refraksi diukur pada umur 2 tahun.

Keputusan: Sebanyak 22 biji mata dari 11 bayi yang mendapat rawatan laser, dan 53 biji mata dari 28 bayi yang tidak mendapat rawatan laser digunakan dalam kajian ini. Kesemua 22 biji mata yang mendapat rawatan laser mempunyai ZON II ROP dengan penyakit plus. Dari jumlah tersebut, 4 mempunyai ROP peringkat 2 manakala 18 mempunyai ROP peringkat 3. Purata berat lahir bagi kumpulan yang dirawat laser dan tidak dirawat laser adalah $966.9 \pm 92.6 \mathrm{~g}$ dan $1019.3 \pm 282.0 \mathrm{~g}$ $(P=0.398)$ secara berturut. Purata umur kehamilan bagi kumpulan yang dirawat laser adalah $28.2 \pm 2.2$ minggu dan yang tidak menerima rawatan laser adalah $27.7 \pm 2.2$ minggu $(P=0.390)$. Pada rawatan susulan 2 tahun, purata sfera setara bagi kumpulan yang dirawat laser dan tidak dirawat laser adalah $-0.55 \pm 2.49 \mathrm{D}$ dan $0.17 \pm 1.43 \mathrm{D}$, namun perbezaannya tidak signifikan $(P=0.120)$. Peratusan miopia adalah lebih tinggi untuk kumpulan yang menerima rawatan (6 mata [27\%] 
berbanding 5 mata [9\%], $P=0.047$ ) dimana 2 biji mata dari 2 bayi yang berbeza (10\%) didapati mempunyai miop tinggi $(>-6.00 \mathrm{D})$. Tidak ada perbezaan statistik yang signifikan untuk hipermetropía dan astigmatisma (semua $P>0.05$ ). Miopia tinggi berkait dengan umur bayi ketika mula menerima rawatan laser $(P=0.025)$. Dalam kumpulan yang dirawat laser, dua bayi (9\%) mempunyai ambliopia dan seorang (5\%) mempunyai eksotropia pada usia 2 tahun. Tiada mata yang mempunyai komplikasi pada struktur retina.

Kesimpulan: Kebanyakan mata bayi ROP yang berjaya dirawat dengan laser mengalami masalah miopia. Ini menunjukkan kepentingan pemeriksaan refraktif susulan untuk kumpulan pesakit ini.

Kata kunci: laser, Malaysia, miopía, kesalahan refraksi, retinopati pramatang

\section{Introduction}

Retinopathy of prematurity (ROP) is a proliferative vascular retinopathy affecting mainly low birth weight and premature infants. It is caused by the abnormal development of retinal blood vessels in premature infants, and may be either mild with no subsequent complications, or aggressive with neovascularisation and even retinal detachment. The prevalence of severe ROP varies from $5 \%$ to $26 \%$ of premature births and is strongly associated with lower birth weight and lower gestational age infants. ${ }^{1}$ Comparison between different population-based studies is difficult because of variability in study designs, gestational ages of included infants, survival rates, and treatments used. In 2017, the Malaysian National Neonatal Registry (MNNR) reported that from a total of 16,449 babies in the NICU of 44 participating hospitals, $20.2 \%$ of babies were born below 32 weeks' gestation and $22.9 \%$ had birth weights of $1,500 \mathrm{~g}$ and below. ${ }^{2}$ Of the 1,899 premature infants who underwent ROP screening, $13.3 \%$ had ROP stages 1 and 2, and $2.2 \%$ had ROP stage $3 .^{2}$ With advances in neonatology allowing better survival of infants with extremely low gestational age and birth weight, it is anticipated that there will be an increase in the number of ROP cases in the future.

Globally, ROP is the leading cause of vision-threatening conditions in infants, ranging from $33 \%$ to $73 \% .^{3}$ Myopia is the most common sequelae, accounting for up to $80 \%$ of infants with ROP. Even in successful anatomical outcomes, severe myopia remains an important cause of visual impairment, especially in eyes that have received laser treatment. The Early Treatment for Retinopathy of Prematurity (ETROP) study revealed an increased prevalence of myopia and high myopia in eyes with laser-treated ROP than in eyes with spontaneously regressed ROP without laser treatment. ${ }^{4}$ Other complications of ROP include strabismus ( $23 \%$ to $47 \%$ ), ${ }^{3}$ amblyopia (19\% to 53\%), ${ }^{5,6}$ retinal detachment $(22 \%),{ }^{7}$ and acute angle-closure glaucoma, which can occur in cicatricial ROP. ${ }^{8}$ 
There is limited data on refractive outcomes of laser-treated ROP eyes in the Malaysian population. In this study, we set out to report the refractive outcome at the 2-year follow-up among laser-treated and non-laser treated (observed) ROP infants in Hospital Selayang.

\section{Methods}

This was a retrospective study of the medical records of pre-term infants with ROP born in Hospital Selayang between 2016 and 2018. This study adhered to the tenets of the Declaration of Helsinki and ethical approval was obtained from the Ethical Committee for Medical Research in Hospital Selayang (research ID: 61604). Infants were included in the study if they were born at or less than 32 weeks of gestation, had a birth weight of $1,500 \mathrm{~g}$ or below, were diagnosed with ROP, and completed 2 years of eye clinic follow-up. Infants were excluded if they were treated with intravitreal anti-VEGF, given cryotherapy, or had incomplete medical records. ROP was classified based on the International Classification of Retinopathy of Prematurity (Table 1). ${ }^{9}$ This classification reported ROP by retinal zone involvement, severity, extension in clock hours, and the presence or absence of plus disease. The infants were divided into two groups: ROP treated with laser and ROP which was observed. Laser treatment was given to infants with threshold and high-risk, pre-threshold ROP (indications as in Table 2, based on the 2005 Malaysian Clinical Practice Guidelines on ROP). ${ }^{10-12}$

When indicated, laser treatment was administered within 72 hours of diagnosis. Panretinal photocoagulation was applied to the avascular retina from the ridge to the ora serrata in a near-confluent manner, via laser indirect ophthalmoscopy with indentation by two trained ophthalmologists in the neonatal care unit. Once ROP had regressed and the retina had completed vascularization, the infants were followed up for cycloplegic refraction, fundus examination, and strabismus or other ROP sequelae. Refractive errors were documented at 1 and 2 years of age. Myopia was defined as an eye condition in which the spherical equivalent (SE) refractive error is $\geq-0.5 \mathrm{D}$ when ocular accommodation is relaxed. Myopia was divided into two categories: low myopia $(-0.50 \mathrm{D}$ to $<-6.00 \mathrm{D})$ and high myopia $(\geq-6.00 \mathrm{D}) .^{13}$ Hypermetropia was divided into low $(<+5.00 \mathrm{D})$ and high $(>+5.00 \mathrm{D})$. Astigmatism was classified as high if $\geq-2.00 \mathrm{D}^{14}$ Data were analysed using SPSS version 26 (IBM Corporation, Armonk, NY, USA). Independent t-tests were used for comparison of continuous variables, and chi-square tests for categorical variables. Pearson correlation analysis was used to assess the correlation of myopic progression in the laser-treated ROP group, with gestational age, birth weight, stage of disease, total number of laser shots received, and post-conceptual age when receiving laser therapy. 
Table 1. The International Classification of Retinopathy of Prematurity ${ }^{9}$

\begin{tabular}{|l|l|}
\hline \multicolumn{2}{|l|}{ Location } \\
\hline Zone I & Posterior retina within a $60^{\circ}$ circle centred on the optic nerve \\
\hline Zone II & Extends from the edge of zone I centrifugally to the nasal ora serrata \\
\hline Zone III & Residual crescent of retina anterior to zone II \\
\hline Extent & Number of clock-hours involved \\
\hline Severity \\
\hline Stage 0 & Immature retinal vasculature with no ROP \\
\hline Stage 1 & Demarcation line between vascularized and avascular retina \\
\hline Stage 2 & $\begin{array}{l}\text { Ridge (demarcation line with height, width, and volume) } \pm \text { small tufts of } \\
\text { neovascular tissues }\end{array}$ \\
\hline Stage 3 & Ridge with extraretinal fibrovascular proliferation \\
\hline Stage 4 & Partial retinal detachment \\
\hline 4A & Extrafoveal detachment \\
\hline 4B & Retinal detachment includes fovea \\
\hline Stage 5 & Total retinal detachment \\
\hline $\begin{array}{l}\text { Plus } \\
\text { disease }\end{array}$ & $\begin{array}{l}\text { Vascular dilatation (venous) and tortuosity (arteriolar) of posterior retinal } \\
\text { vessels in at least 2 quadrants of the retina }\end{array}$ \\
\hline
\end{tabular}

Table 2. Criteria for laser treatment in ROP (based on Malaysian Clinical Practice Guidelines on ROP, 2005) $)^{10-12}$

\begin{tabular}{|l|l|}
\hline Threshold disease & High-risk, pre-threshold disease \\
\hline $\begin{array}{l}\text { Defined as having all the following: } \\
\text { Stage 3 ROP in zone I or zone II } \\
\text { Involving 5 or more contiguous clock hours; } \\
\begin{array}{l}\text { or } 8 \text { or more cumulative clock hours } \\
\text { Presence of plus disease }\end{array}\end{array}$ & $\begin{array}{l}\text { Defined as any of the following: } \\
\text { Zone I, stage 3 ROP without plus disease } \\
\text { Zone II, stage 2 or 3 ROP with plus disease }\end{array}$ \\
\hline
\end{tabular}




\section{Results}

There were 56 premature infants with ROP of various stages born at Hospital Selayang between 2016 and 2018. Of these, 13 infants received laser treatment while 43 were observed. This study included 22 eyes of 11 infants that received laser treatment for ROP and 53 eyes of 28 infants that were only observed (two infants in the laser-treated ROP group and 15 in the non-laser-treated ROP group were lost to follow-up at the 2-year stage). Among the laser-treated infants, all had bilateral ROP involving zone II and thus received bilateral laser treatment. Of the total, four eyes had stage 2 ROP with plus disease, and the remaining 18 eyes had stage 3 ROP with plus disease. Four eyes had threshold disease and 18 eyes had pre-threshold disease. No infants had aggressive posterior ROP (APROP). As for the observed group, three infants had unilateral disease and two infants had pre-plus disease. Thirty eyes had zone II ROP, and 23 eyes had zone III ROP. There were 32 eyes with stage 1 ROP and 21 eyes with stage 2 ROP. There were no infants with stage 3 ROP, or ROP involving zone I in the observed group. Table 3 summarises the characteristics of the study population and laser parameters. Retreatment with laser was not required by any of the study infants.

Table 3. Characteristics of the study population

\begin{tabular}{|c|c|c|c|}
\hline \multirow[t]{2}{*}{ Parameters } & \multicolumn{2}{|l|}{ Mean \pm SD (range) } & \multirow[b]{2}{*}{$\begin{array}{l}p \text {-value* } \\
(95 \% \mathrm{CI})\end{array}$} \\
\hline & Laser-treated ROP & $\begin{array}{l}\text { Non-laser-treated } \\
\text { ROP }\end{array}$ & \\
\hline $\begin{array}{l}\text { Mean gestational age } \\
\text { (weeks) }\end{array}$ & $28.2 \pm 2.2(26-32)$ & $27.7 \pm 2.2(25-35)$ & $\begin{array}{l}0.390 \\
(-0.6 \text { to } 1.6)\end{array}$ \\
\hline $\begin{array}{l}\text { Mean birth weight } \\
\text { (grams) }\end{array}$ & $\begin{array}{l}966.9 \pm 92.6 \\
(790-1075)\end{array}$ & $\begin{array}{l}1019.3 \pm 282.0 \\
(586-1750)\end{array}$ & $\begin{array}{l}0.398 \\
(-175.3 \text { to } 70.5)\end{array}$ \\
\hline $\begin{array}{l}\text { Post-conceptual age } \\
\text { when receiving laser } \\
\text { treatment (weeks) }\end{array}$ & $\begin{array}{l}40 w 5 d \pm 2 w 5 d \\
(36 w-44 w)\end{array}$ & - & - \\
\hline $\begin{array}{l}\text { Total number of laser } \\
\text { shots }\end{array}$ & $\begin{array}{l}2738.9 \pm 708.4 \\
(1707-4682)\end{array}$ & - & - \\
\hline Laser energy (mw) & $238.2 \pm 42.8(180-340)$ & - & - \\
\hline
\end{tabular}

${ }^{*}$ t-test 


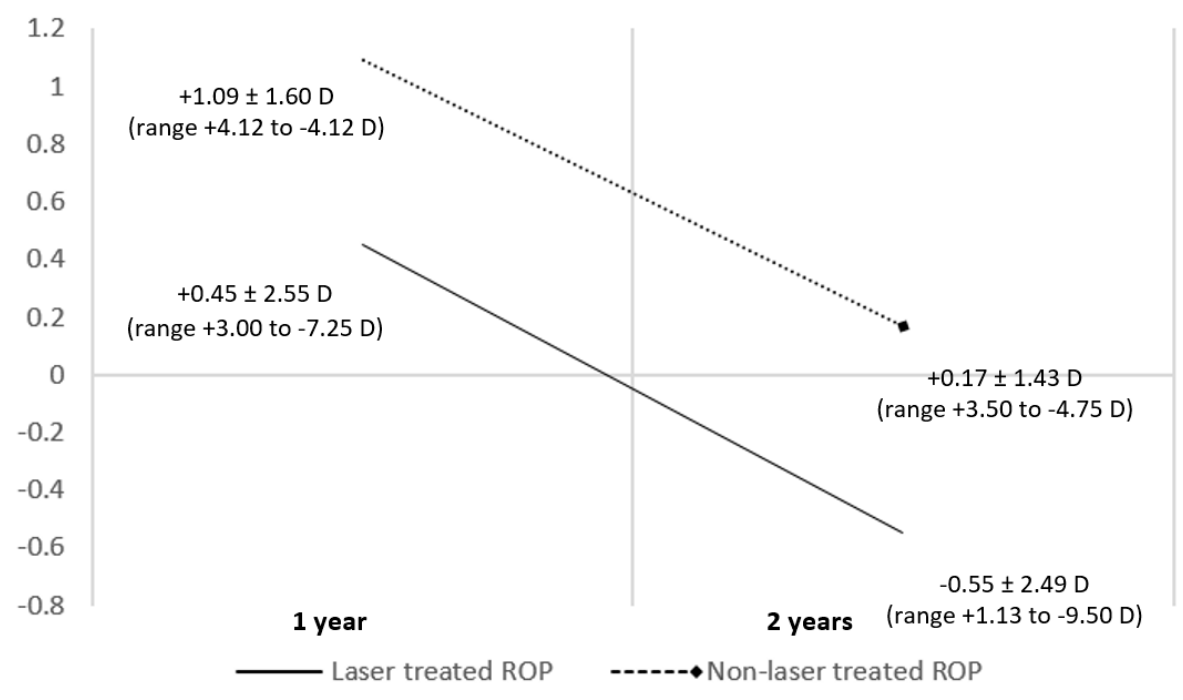

Fig. 1. Spherical equivalence outcomes at 1 and 2 years of age (mean $\pm S D$ ). Note that differences between the groups at both 1 and 2 years were not statistically significant $(P=$ 0.194 and $P=0.120$, respectively).

Both groups of ROP eyes showed gradual increase in myopia at 2 years (Fig. 1). At 2 years, the mean SE for the laser-treated and non-laser treated groups was $-0.55 \pm$ $2.49 \mathrm{D}$ and $+0.17 \pm 1.43 \mathrm{D}$, respectively, although the difference was not statistically significant $(P=0.120)$. Table 4 summarises the refractive outcome at 2 years. Two eyes (9\%) from two different infants had high myopia, with SE of $-9.50 \mathrm{D}$ and -6.25 $\mathrm{D}$, and both developed amblyopia needing treatment with contact lenses and eye patching. These eyes with high myopia received laser treatment at earlier post-conceptual ages of 36 weeks (for stage 3, zone II with plus and threshold disease) and 38 weeks (for stage 3 , zone II with plus disease and pre-threshold disease), respectively. One infant (5\%) had exotropia. All eyes had a favourable anatomical outcome and none of the eyes showed structural posterior pole sequelae such as narrowing of arcades, disc or macular dragging, vitreous membranes, or peripheral tractional retinal detachment. Pearson correlation analysis of myopic progression in the laser-treated ROP group with gestational age, birth weight, stage of disease, and total number of laser shots received showed non-statistically significant correlations (all $p>0.05$ ). However, there was a statistically significant correlation between development of myopia and post-conceptual age when receiving laser therapy $(r=$ $0.49, p=0.025$ ). 
Table 4. Refractive error at 2 years of age

\begin{tabular}{|c|c|c|c|}
\hline Refractive error & $\begin{array}{l}\text { Laser-treated ROP } \\
n(\%)\end{array}$ & $\begin{array}{l}\text { Non-laser-treated ROP } \\
n(\%)\end{array}$ & $\begin{array}{l}p \text {-value }{ }^{\star} \\
\left(X^{2} \text { value }\right)\end{array}$ \\
\hline $\begin{array}{l}\text { Myopia } \\
\text { Low myopia } \\
\text { High myopia }\end{array}$ & $\begin{array}{l}6(27 \% \text {, range }-0.50 \text { to } \\
-9.00 \mathrm{D}) \\
4(18 \%) \\
2(9 \%)\end{array}$ & $\begin{array}{l}5(9 \% \text {, range }-0.50 \text { to }-3.00 \\
\text { D) } \\
3(6 \%) \\
-\end{array}$ & $\begin{array}{l}0.047(3.9) \\
0.090(2.9) \\
-\end{array}$ \\
\hline Hypermetropia & $\begin{array}{l}15(68 \% \text {, range }+1.75 \text { to } \\
+0.25 \mathrm{D})\end{array}$ & $\begin{array}{l}36(68 \% \text {, range }+3.50 \text { to } \\
+0.50 \mathrm{D})\end{array}$ & $0.983(0.0)$ \\
\hline Emmetropia & $1(5 \%)$ & $12(23 \%)$ & $0.059(3.6)$ \\
\hline $\begin{array}{l}\text { Astigmatism } \\
\text { High astigmatism }\end{array}$ & $\begin{array}{l}16(73 \% \text {, range }-0.50 \text { to } \\
-2.50 \mathrm{D}) \\
1(5 \%)\end{array}$ & $\begin{array}{l}43(81 \% \text {, range }-0.50 \text { to } \\
-3.50 \mathrm{D}) \\
3(6 \%)\end{array}$ & $\begin{array}{l}0.419(0.7) \\
0.845(0.0)\end{array}$ \\
\hline
\end{tabular}

*Pearson chi-square test $\left(X^{2}\right)$

\section{Discussion}

In our study population, the mean birth weight and gestational age for laser-treated ROP infants was $966.9 \mathrm{~g}$ and 28.2 weeks, respectively. These are consistent with data from other Asian countries that report higher birth weights and gestational ages compared to Western studies. ${ }^{14-18}$ For example, the ETROP study from the United States reported mean birth weight and gestational age as $703 \mathrm{~g}$ and 25 weeks, respectively. ${ }^{18}$ These differences may be attributed to ethnic variations, and increased survivability of lower birth weight and younger infants in Western or more developed countries.

In our study, although not statistically significant, the SE at 2 years was more myopic for the laser-treated group than for the non-laser treated group $(-0.55 \pm 2.49$ D versus $+0.17 \pm 1.43 \mathrm{D}$, respectively). The mean change of SE in 1 year duration for the laser-treated and non-laser treated groups was $-1.00 \pm 1.10 \mathrm{D}$ and $-0.94 \pm 0.96$ $D$, respectively $(p=0.813)$. We wonder if statistical significance would have been reached with a larger sample size. The myopia rate for our laser-treated patients was $27 \%$, with presence of high myopia in $9 \%$. This compares to only $9 \%$ with myopia and no cases of high myopia in the observed group. Our rates are similar to those reported by Katoch et al., where from a total of 69 laser-treated ROP eyes, $24.7 \%$ of eyes had low myopia and $1 \%$ had high myopia. ${ }^{19}$ In general, this pattern of higher prevalence and greater severity of myopia among laser-treated ROP was also 
seen in other studies with onset as early as 6 months to 3 years. ${ }^{4,14,16,20} \mathrm{~A}$ literature review on refractive errors in laser-treated ROP eyes (Table 5) shows a difference in prevalence of myopia ranging from $26 \%$ to $93 \%$. Again, we believe this large range in myopia rates is due to the variability in study design, study population in terms of cultural diversity and access to health care, gestational ages of included infants, survival rates, and treatment used. It is postulated that tissue destruction from the laser-treated avascular peripheral retina may cause alterations in the development and maturation of the zonules, ciliary body, and lens. ${ }^{5}$ While premature infants without ROP or those with spontaneous resolution of ROP may also develop myopia, the magnitude is lower compared with treated ROP. ${ }^{21,22}$

Most studies have reported that the prevalence of myopia is positively correlated with lower birth weight and greater severity of ROP. ${ }^{3,19,23}$ Few studies have also found that progression to myopia is associated with a greater number of clock hours of ROP, a greater number of laser spots, and a longer time for disease regression. ${ }^{16,24}$ In this study, there was no statistically significant correlation between myopic progression and either gestational age, birth weight, stage of ROP, or total number of laser shots received. However, we report a statistically significant association of myopia with younger post-conceptual age when laser treatment was first given. This finding is similar to that of Lok et al., where it was suggested to be related to increased susceptibility of eyes towards laser therapy and more aggressive ROP presented at an earlier age of life. ${ }^{25}$

Currently, the recommended treatment for ROP is laser ablation to the peripheral avascular retina for eyes with threshold disease and high-risk, pre-threshold disease. Unfortunately, this laser therapy may destroy the peripheral retina, leading to peripheral vision loss. Recently, intravitreal injection of anti-vascular endothelial growth factor (anti-VEGF), especially bevacizumab and ranibizumab, has been used as an alternative treatment and has offered benefit for disease stages previously not responsive or unsuitable for the standard laser therapy. ${ }^{26}$ The use of anti-VEGF agents for the treatment of ROP is increasing worldwide. However, several aspects of anti-VEGF remain controversial, including its ocular efficacy, appropriate drugs and dosage, need for retreatment, and possibility of long-term systemic effects. ${ }^{27,28}$ Anti-VEGF treatment has been speculated to provide better refractive outcomes. ${ }^{29}$ However, it is still early to conclude the visual outcomes and confirm the long-term systemic safety. Both treatments of ROP, be it laser or intravitreal anti-VEGF, carry their own risks and benefits. Nevertheless, the risk of complications due to untreated ROP outweigh the risk of complications from laser or anti-VEGF treatment. The treatment choice also depends on the parents' decisions and medication costs. In Hospital Selayang, intravitreal anti-VEGF treatment for ROP was only started in 2019 and has involved relatively few infants so far.

A few limitations of this study include the retrospective nature of data collection, a relatively small number of eyes analysed, and short duration of follow-up. There was also limited information pertaining the extent of the laser treatment given in 


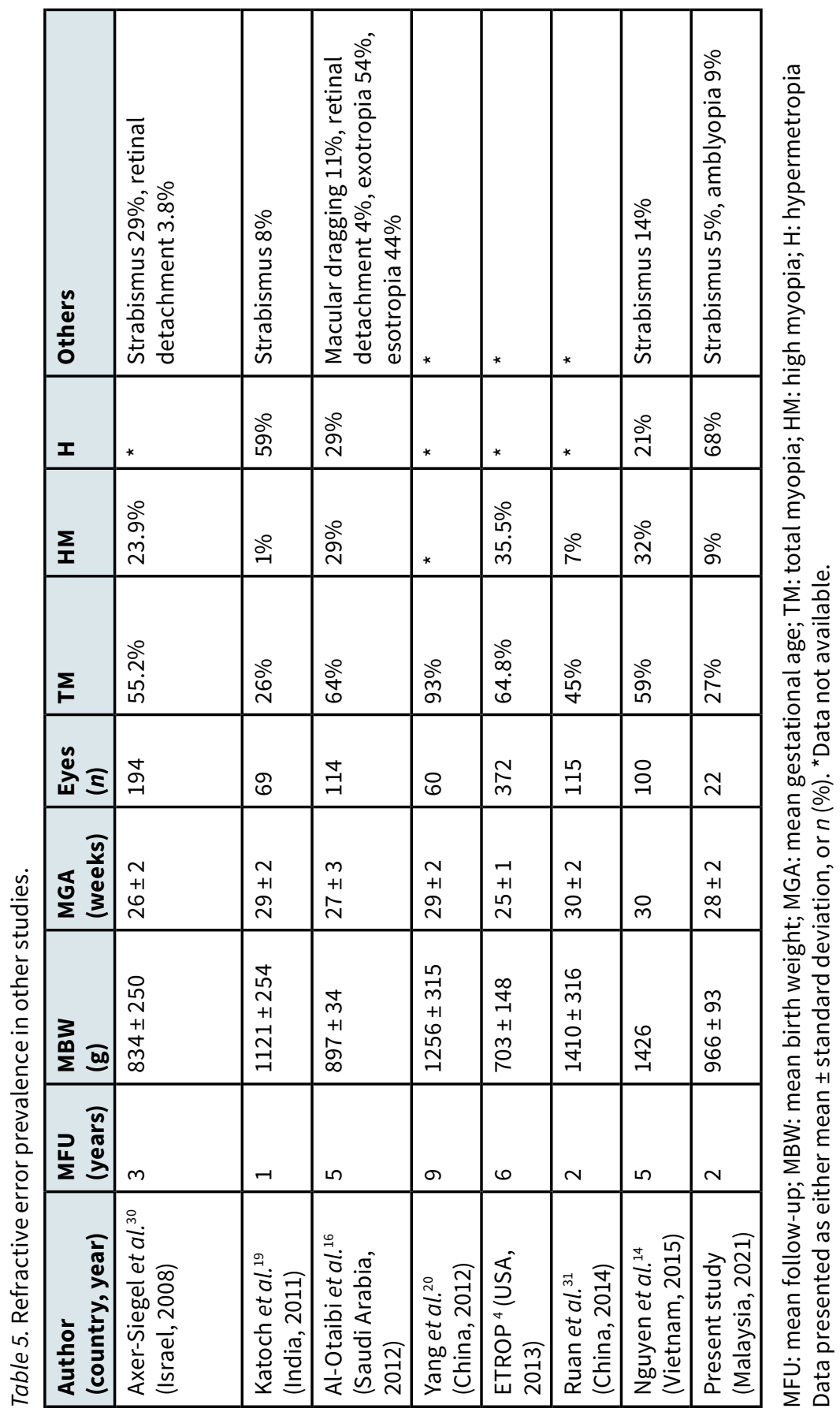


the medical records. Our study, however, is still very relevant as there is limited data from Malaysia on the refractive outcomes of laser-treated ROP. We recommend further research into this less known topic for the Malaysian population to improve treatment regimens for sight-threatening ROP.

\section{Conclusion}

Despite achieving favourable anatomical outcomes, a significant proportion (27\%) of laser-treated ROP eyes developed myopia at 2 years of age. This earlier emmetropisation may lead to the development of high myopia as the child grows, which may in turn lead to amblyopia or other complications from high myopia. This highlights the need for regular refractive screening and follow-up after laser treatment of ROP and treatment where appropriate to optimise the visual potential and outcomes in children.

\section{Declarations}

\section{Ethics approval and consent to participate}

This was a retrospective study of the medical records of pre-term infants with ROP born in Hospital Selayang between 2016 and 2018. This study adhered to the tenets of the Declaration of Helsinki and ethical approval was obtained from the Ethical Committee for Medical Research in Hospital Selayang (research ID: 61604).

\section{Competing interests}

The authors declare no conflicts of interest with respect to the publication of this article.

\section{Funding}

The authors received no financial funding for the research, authorship, and/or publication of this article.

\section{Acknowledgements}

The authors wish to thank the Director General of Health Malaysia for permission to publish this article. 


\section{References}

1. Hellstrom A, Smith LEH, Dammann O. Retinopathy of prematurity. Lancet.2013;382(9902):144-1457.

2. Malaysian National Neonatal Registry and Clinical Research Centre, Ministry of Health Malaysia, Kuala Lumpur 2017. Available from: http://www.acrm.org.my/mnnr

3. O'Connor AR, Stephenson T, Johnson A, et al. Long-term ophthalmic outcome of LBW children with and without ROP. Paediatrics. 2002;109(1):12-8

4. Quinn GE, Dobson V, Davitt BV. Early Treatment for Retinopathy of Prematurity Cooperative Group. Progression of myopia and high myopia in the Early Treatment for Retinopathy of Prematurity study: findings at 4 to 6 years of age. J AAPOS. 2013;17(2):124-128.

5. Yang CS, Wang AG, Shih YF, Hsu WM. Long-term biometric optic components of diode laser-treated threshold retinopathy of prematurity at 9 years of age. Acta Ophthalmol. 2013;91:276-282.

6. Yang CS, Wang AG, Sung CS, Hsu WM, Lee FL, Lee SM. Long-term visual outcomes of laser-treated threshold retinopathy of prematurity: A study of refractive status at 7 years. Eye. 2010;24:14-20.

7. Cryotherapy for Retinopathy of Prematurity Cooperative Group. Multicenter trial of cryotherapy for retinopathy of prematurity: ophthalmological outcome at 10 years. Arch Ophthalmol. 2001:119(8);1110-1118.

8. Ritch R, Chang BM, Liebmann JM. Angle closure in younger patients. Ophthalmology. 2003;110:18801889.

9. Chiang MF, Quinn GE, Fielder AR, et al. International Classification of Retinopathy of Prematurity, 3rd edition. Ophthalmology. 2021;128:00416-4.

10. Ministry of Health Malaysia; Academy of Medicine Malaysia. Clinical Practice Guidelines: Retinopathy of Prematurity. Putrajaya: Ministry of Health Malaysia; 2005.

11. Early Treatment for Retinopathy of Prematurity Cooperative Group. Revised indications for the treatment of retinopathy of prematurity: results of the early treatment for retinopathy of prematurity randomized trial. Arch Ophthalmol.2003;121(12):1684-1694.

12. Reynolds JD, Dobson V. Evidence-based screening criteria for retinopathy of prematurity: natural history data from the CRYO-ROP and LIGHT-ROP studies. Arch Ophthalmol. 2002;120(11):1470-1476.

13. Flitcroft DI, He M, Jonas JB, et al. IMI - Defining and classifying myopia: a proposed set of standards for clinical and epidemiologic studies. Invest Ophthalmol Vis Sci. 2019;60:20-30.

14. Nguyen PH, Catt C, Nguyen TX, Pham VT. Refractive outcome of prethreshold retinopathy of prematurity treated by diode laser: follow-up at 5 years. Clin Ophthalmol. 2015:9;1753-1758.

15. Vinekar A, Dogra MR, Sangtam T, Narang A, Gupta A. Retinopathy of prematurity in Asian Indian babies weighing greater than 1250 grams at birth: Ten year data from a tertiary care center in a developing country. Indian J Ophthalmol. 2007;55:331-336.

16. Al-OtaibiAG, Aldrees SS, MousaAA. Long term visual outcomes in laser treated threshold retinopathy of prematurity in Central Saudi Arabia. Saudi J Ophthalmol. 2012;26(3):299-303.

17. Lee GA, Hilford DJ, Gole GA. Diode laser treatment of pre-threshold and threshold retinopathy of prematurity. Clin Exp Ophthalmol. 2004;32(2):164-169.

18. Early Treatment for Retinopathy of Prematurity Cooperative Group. Final results of the early treatment for retinopathy of prematurity (ETROP) randomized trial. Trans Am Ophthalmol Soc. 2004;102:233-250. 
19. Katoch D, Sanghi G, Dogra MR, Beke N, Gupta A. Structural sequelae and refractive outcome 1 year after laser treatment for type 1 prethreshold retinopathy of prematurity in Asian Indian eyes. Indian J Ophthalmol. 2011;59:423-426.

20. Yang CS, Wang AG, Shih YF, Hsu WM. Astigmatism and biometric optic components of diode laser-treated threshold retinopathy of prematurity at 9 years of age. Eye. 2013;27(3):374-381.

21. Cook A, White S, Batterbury M, Clark D. Ocular growth and refractive error development in premature infants with or without retinopathy of prematurity. Invest Ophthalmol Vis Sci. 2008;49(12):51995207.

22. Sahni J, Subhedar NV, Clark D. Treated threshold stage 3 versus spontaneously regressed subthreshold stage 3 retinopathy of prematurity: a study of motility, refractive, and anatomical outcomes at 6 months and 36 months. Br J Ophthalmol. 2005;89(2):154-159.

23. Fledelius HC. Myopia of prematurity, clinical patterns. A follow-up of Danish children now aged 3-9 years. Acta Ophthalmol. 1995;73:402-406.

24. Early Treatment for Retinopathy of Prematurity Cooperative Group. Prevalence of myopia and high myopia in the early treatment for retinopathy of prematurity study. Ophthalmology. 2008;115:105864.

25. Lok JYC, Yip WWK, Luk ASW, Chin JKY, Lau HHW, Young AL. Visual outcome and refractive status in first 3 years of age in preterm infants suffered from laser-treated Type 1 retinopathy of prematurity (ROP): a 6-year retrospective review in a tertiary centre in Hong Kong. Int Ophthalmol. 2018;38(1):163-169

26. Pan American Health Organization. Clinical Practice Guidelines for the Management of Retinopathy of Prematurity. Summarized Version 2017. Washington, DC: PAHO; 2019.

27. Mintz-Hittner HA, Kennedy KA, Chuang AZ, BEAT-ROP Cooperative Group. Efficacy of intravitreal bevacizumab for stage 3+ retinopathy of prematurity. N Engl J Med. 2011;364(7):603-15.

28. Stahl A, Lepore D, Fielder A, et al. Ranibizumab versus laser therapy for the treatment of very low birth weight infants with retinopathy of prematurity (RAINBOW): An open-label randomised controlled trial. Lancet. 2019; 394:1551-1559.

29. Gelonek MM, Chuang AZ, Clark WL, et al. and the BEAT-ROP Cooperative Group. Refractive outcomes following bevacizumab monotherapy compared with conventional laser treatment. JAMA Ophthalmol. 2014;132:1327-1333.

30. Axer-Siegel R, Maharshak I, Snir M, et al. Diode laser treatment of retinopathy of prematurity: anatomical and refractive outcomes. Retina. 2008;28(6):839-846.

31. Ruan L, Shan HD, Liu HZ, Huang X. Refractive Status of Chinese with Laser-Treated Retinopathy of Prematurity. Optom Vis Sci. 2014;92:3-9. 